\title{
Economic Evaluation of Early Sex Determination for Farmed Russian Sturgeon: The Case of Northern Israel
}

\author{
Gregory Yom Din ${ }^{*}$, Gad Degani1,2 \\ ${ }^{1}$ Tel-Hai Academic College, Upper Galilee, Israel \\ ${ }^{2}$ MIGAL - Galilee Research Institute, Kiryat Shmona, Israel \\ Email: *gregoryyd@gmail.com
}

How to cite this paper: Yom Din, G., \& Degani, G. (2020). Economic Evaluation of Early Sex Determination for Farmed Russian Sturgeon: The Case of Northern Israel. Modern Economy, 11, 1977-1983.

https://doi.org/10.4236/me.2020.1112132

Received: October 28, 2020

Accepted: December 6, 2020

Published: December 9, 2020

Copyright $\odot 2020$ by author(s) and Scientific Research Publishing Inc. This work is licensed under the Creative Commons Attribution International License (CC BY 4.0).

http://creativecommons.org/licenses/by/4.0/

\begin{abstract}
Sturgeon farming has high potential economic value, but the industry is characterized by late fish maturity, leading to a long payback period for sturgeon farms. Early sex determination (ESD) of fish is important for increasing the profitability of sturgeon farms due to early male separation, thus enabling growing more females and producing more caviar for the same farm area. The data for Russian sturgeons farmed in northern Israel and the results of molecular markers developed for ESD are used in this study. Two sturgeon sex determination technologies are examined and compared from an economic point of view: 1) using molecular DNA markers for ESD at the age of 0.5 years; and 2) using endoscopic methods at the age of 3.5 years, as is currently done in many sturgeon farms. For this purpose, a bio-economic model of a sturgeon farm was developed and an economic evaluation of a sturgeon farm was made to compare both technologies. The ESD technology results in a significant improvement in the economic performance of sturgeon farms. This improvement is greater when caviar prices are lower.
\end{abstract}

\section{Keywords}

Aquaculture, Bio-Economic Model, DNA Marker, Early Sex Determination, Sturgeon

\section{Introduction}

The sturgeon aquaculture industry is growing worldwide. In 2017, there were more than 2300 industrial sturgeon farms (Bronzi et al., 2019). The annual production of caviar-this industry's main product-increased from 260 tons in 
2012 to 364 tons in 2017 and estimates for the future 10 years from 500 to 2000 tons (Sicuro, 2019; Bronzi et al., 2019). The industry is characterized by late fish maturity, resulting in no caviar production before year 7 . This leads to a long payback period for sturgeon farms that is sensitive to additional biological and market parameters, such as caviar output and price.

Since 1992, Russian sturgeon (Acipenser gueldenstaedtii) has been farmed along the Dan River in northern Israel. Males are separated at the age of 3.5 years and sold for meat (at a relatively low producer price). Females continue to be grown to produce caviar at the age of 7 - 10 years. Endoscopic methods for sex determination are currently used on this farm, similar to many other sturgeon farms worldwide (Hurvitz et al., 2007). Early sex determination (ESD) of fish using molecular DNA markers at the age of 0.5 years could increase the profitability of sturgeon farms due to early male separation, which would enable growing more females and producing more caviar per unit farm area.

A study of transcriptome differences between male and female sturgeon and identification of key genes that might contribute to ESD were conducted using sturgeons farmed in this region in Israel (Degani et al., 2019). Transcriptome studies of sexual variation in gene expression have been conducted in the Russian sturgeon (Hagihara et al., 2014; Chen et al., 2016) and other sturgeon species (Jin et al., 2015; Wang et al., 2017; Burcea et al., 2018; Chen et al., 2018), and additional candidate genes have been identified: generally high transcription of dmrt1 mRNA in males and of foxl2 and cyp19a1 mRNA in females (Fajkowska et al., 2016). Based on this molecular method, it can be assumed that ESD in Russian sturgeon farms can be executed in the middle of year 1 of the male's life and not, as is currently done, using endoscopic methods in year 4 .

There are no external differences that allow for ESD without molecular methods for Russian sturgeon. From an economic standpoint, breeders are interested in identifying females, which produce caviar of very high economic value, and getting rid of the males, whose economic value is low. The endoscopic methods for determining sex can be only used once the gonads differentiate, at the age of 3 years or later. The sample needed for the suggested ESD is taken, not from the gonads, but from the dorsal fin (tissue) of the 6-month-old fish using a molecular method that can discern sex several months before sex differentiation based on a DNA variation (this was shown in research at the Dan River sturgeon farm, unpublished data).

In this study, we hypothesized that using ESD will enable allocating greater resources for breeding females, instead of the current spending of farm resources on raising males. The drawback of sex determination in a sturgeon farm without using the ESD molecular method is that males are grown for $3-4$ years, which reduces the volume of water available in the farm for raising more females. The traditional technique of sex determination by endoscopic methods involves anesthesia and a great deal of work by technicians. The technology for ESD is relatively inexpensive, requires less labor (no expensive endoscopic methods are 
needed), and can be applied to fish at the age of half a year.

To examine the economic importance of this innovation, we are planning in this study to compare the profitability of sturgeon farming with and without ESD. To this end, we developed a bio-economic model of a Russian sturgeon farm and estimated it using data relevant for northern Israel to provide researchers and practitioners with insight on the expected profitability of ESD. Our approach could be readily generalized to other technological innovations in sturgeon farms.

\section{Materials and Methods}

\subsection{Empirical Bio-Economic Model for Planning the Sturgeon Farm}

Based on the pond-rearing technology used in the Dan River sturgeon farm in northern Israel (Figure 1; Hurvitz \& Markel, 2015), the following bio-economic model of a sturgeon farm was developed (Figure 2).

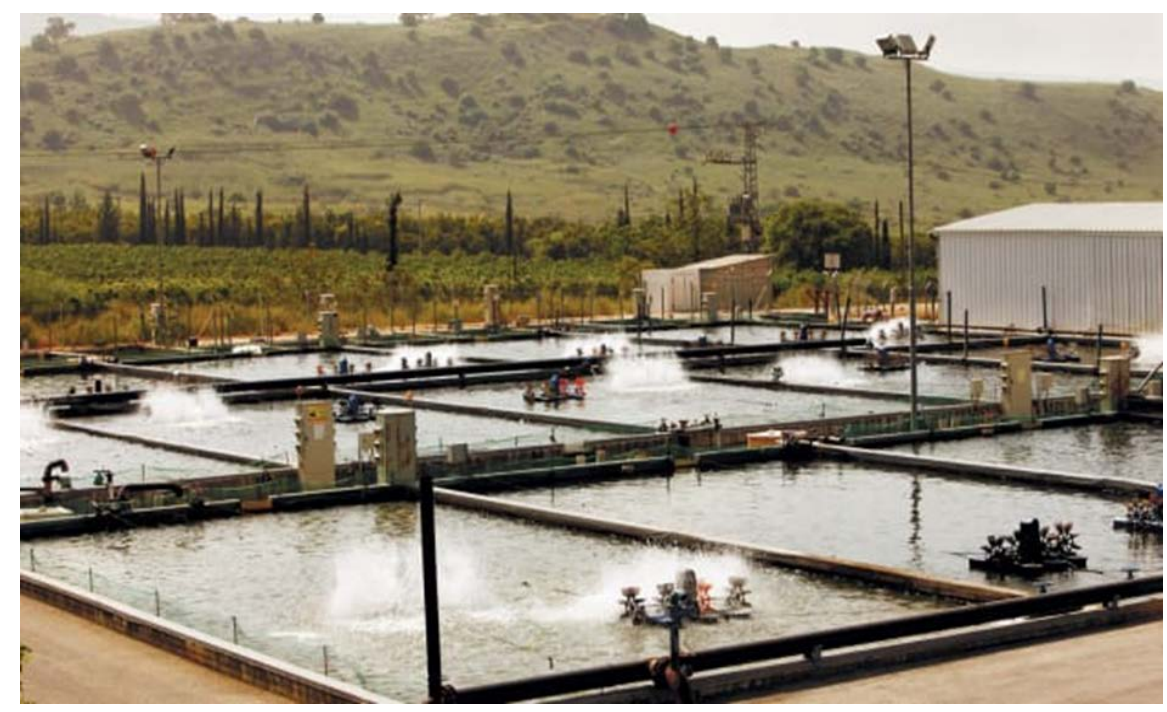

Figure 1. The ponds of the Dan River sturgeon farm.

\begin{tabular}{|c|c|c|c|c|}
\hline \multirow{2}{*}{$\begin{array}{l}\text { Financial, technological } \\
\text { assumptions }\end{array}$} & farm size & \multicolumn{3}{|c|}{ Fish population movement } \\
\hline & \multirow{2}{*}{$\begin{array}{l}\text { ESD } \\
\text { parameters }\end{array}$} & & & \\
\hline & & \multirow[b]{2}{*}{ year 1} & Without ESD & With ESD \\
\hline $\begin{array}{l}\text { Investment, financing } \\
\text { Revenue-caviar, fish }\end{array}$ & fish number & & females/males & females/males \\
\hline $\begin{array}{l}\text { Expenses-feed, eggs, } \\
\text { labor, water, other } \\
\text { Financial analysis }\end{array}$ & production & year 2 & females/males & females \\
\hline compared by versions & & $\cdots$ & & \\
\hline Output of the model & & year 10 & females & females \\
\hline
\end{tabular}

Figure 2. Flow-chart of the bio-economic model of a sturgeon farm. 
The farm is planned to rear and grow 70,000 sturgeons annually, both with and without ESD. For the same pond area of the farm in the version with ESD, the number of females reared is planned to be $21 \%$ greater than the version without ESD. In the model schedule, one year is planned as an investment period and seven years from hatchery for females to arrive at maturity. Caviar production is planned for years 7 (10\% of all females of this age), 8 (70\%), 9 $(10 \%)$ and $10(10 \%)$ due to the data from the Dan River farm. Since sturgeon farming is a slow industry, the model is evaluated for a 25 -year planning horizon. The head-on-gutted (HOG) fish production (females only) is planned from year 7 of fish life. The share of loans in the project's financing is planned at $75 \%$, and equity at the $25 \%$ level. Cash flows of the financial modules of the model are based on monthly scheduling of caviar and HOG fish production.

Thus, the financial estimate for the contribution of a method for sex identification in juvenile fish is based on an about $20 \%$ to $25 \%$ increase in caviar production on the same farm, without the need for additional investments.

\subsection{Data}

The comparative data necessary for running the model for both versions of the technology were taken from published data of the Dan River and other fish farms in Israel (Hurvitz \& Markel, 2015; Озиранский et al., 2017). The technological data included feed consumption ratio for growing, hatching and post-hatching periods, hatchability and survival data, caviar output of $1.93-2.75$ $\mathrm{kg}$ (for fish aged 7 - 10 years) and fish weight of fish populations of various ages on the farm. The economic data included financing assumptions, investment costs of $\$ 14$ million and an initial working capital of $\$ 31.4$ million (as already noted, sturgeon farming is a slow industry), labor costs, purchase prices of feed and other inputs, and production prices of caviar $(\$ 1000 / \mathrm{kg})$ and fish $(\$ 10 / \mathrm{kg})$.

The number of jobs and the cost of goods sold (without feed) was planned at a smaller level for the farm with ESD than for the farm without ESD (3\% and 9\%, respectively). The contribution of ESD to the farm's economic value was measured by comparing the farm's net present value (NPV), internal rate of return (IRR) and payback period.

\section{Results and Conclusion}

The empirical model was developed using Microsoft Excel. The compared financial highlights of the economic evaluation for both versions of the farm are presented in Table 1. Including ESD in the model led to significant changes in the economic evaluation of the sturgeon farm. Besides the indices shown in Table 1 (greater NPV and IRR, shorter payback period of the investment), we note that the cumulative net profit for the total planning period ( 25 years) is $34 \%$ greater when ESD is applied as calculated in the bio-economic model.

Considering the fluctuating caviar market, it is interesting to compare sensitivity to caviar price for economic performance in both versions. For poorer 
market conditions, when caviar prices are lower, the economic advantage in terms of payback period of the farm with ESD is greater than for a market with higher prices. Various prices were considered in running the model; the difference in payback period for the lowest caviar price was 13 months, and for the highest price- 8 months, ceteris paribus, as can be seen in Figure 3. This is important in deciding how reliable the economic advantage of ESD is, and how this technology can mitigate the price drop.

\section{Conclusion}

In this study, an economic evaluation of a Russian sturgeon farm in northern Israel was made using two farming technologies: with and without ESD. The technology with ESD enabled significant improvement in the economic performance of the sturgeon farm. This improvement was greater when caviar production prices were lower.

\section{Acknowledgements}

This study was funded by MIGAL - Galilee Research Institute, Israel.

We are grateful to Dr. Avshalom Horowitz for the advice and guidance for this work.

Table 1. Financial highlights of the sturgeon farm's economic evaluation.

\begin{tabular}{ccc}
\hline Item & Without ESD & With ESD \\
\hline Net Present Value (NPV), \$mln & 49.5 & 69.4 \\
Internal Rate of Return (IRR) & $15.1 \%$ & $17.7 \%$ \\
Payback period, discounted not & 11 years 1 1 \\
Including investment period & month & month \\
\hline
\end{tabular}

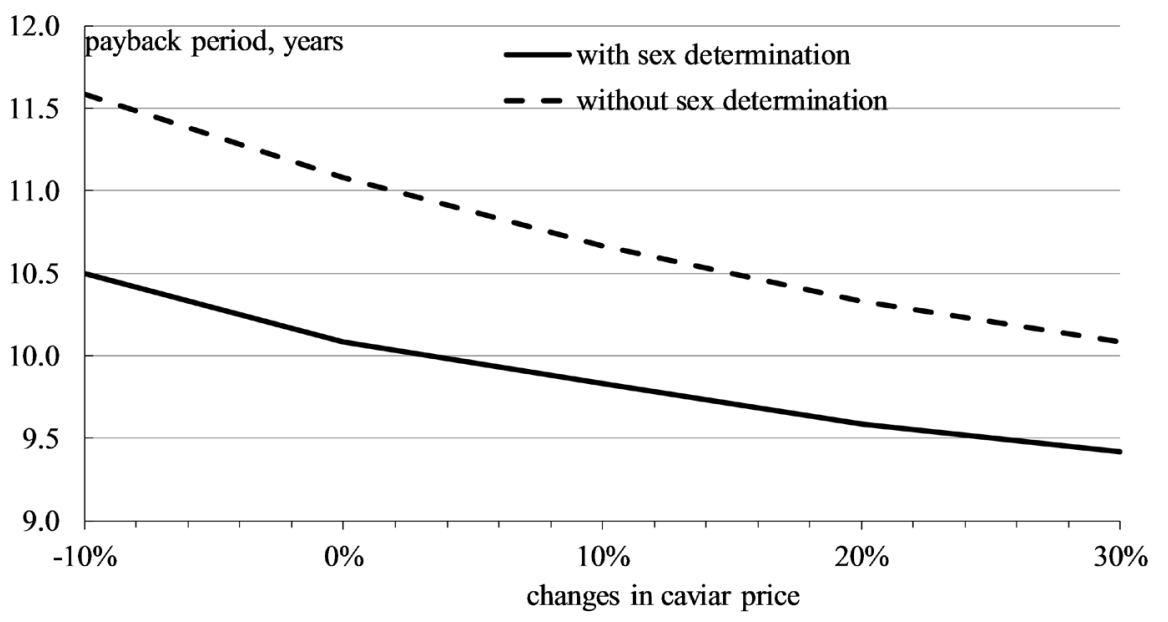

Figure 3. Sensitivity of the sturgeon farm payback period (discounted, not including the investment period) to caviar producer price as follows from the bio-economic model. 


\section{Conflicts of Interest}

The authors declare no conflicts of interest regarding the publication of this paper.

\section{References}

Bronzi, P., Chebanov, M., Michaels, J. T., Wei, Q., Rosenthal, H., \& Gessner, J. (2019). Sturgeon Meat and Caviar Production: Global Update 2017. Journal of Applied Ichthyology, 35, 257-266. https://doi.org/10.1111/jai.13870

Burcea, A., Popa, G. O., Maereanu, M., Dudu, A., Georgescu, S. E., \& Costache, M. (2018). Expression Characterization of Six Genes Possibly Involved in Gonad Development for Stellate Sturgeon Individuals (Acipenser stellatus, Pallas 1771). International Journal of Genomics, 2018, Article ID: 7835637. https://doi.org/10.1155/2018/7835637

Chen, J., Wang, W., Tian, Z., Dong, Y., Dong, T., Zhu, H., Hu, W. et al. (2018). Efficient Gene Transfer and Gene Editing in Sterlet (Acipenser ruthenus). Frontiers in Genetics, 9, 117. https://doi.org/10.3389/fgene.2018.00117

Chen, Y., Xia, Y., Shao, C., Han, L., Chen, X., Yu, M., \& Sha, Z. (2016). Discovery and Identification of Candidate Sex-Related Genes Based on Transcriptome Sequencing of Russian Sturgeon (Acipenser gueldenstaedtii) Gonads. Physiological Genomics, 48, 464-476. https://doi.org/10.1152/physiolgenomics.00113.2015

Degani, G., Hurvitz, A., Eliraz, Y., \& Meerson, A. (2019). Sex-Related Gonadal Gene Expression Differences in the Russian Sturgeon (Acipenser gueldenstaedtii) Grown in Stable Aquaculture Conditions. Animal Reproduction Science, 200, 75-85. https://doi.org/10.1016/j.anireprosci.2018.11.013

Fajkowska, M., Rzepkowska, M., Adamek, D., Ostaszewska, T., \& Szczepkowski, M. (2016). Expression of Dmrtl and Vtg Genes during Gonad Formation, Differentiation and Early Maturation in Cultured Russian Sturgeon Acipenser gueldenstaedtii. Journal of Fish Biology, 89, 1441-1449. https://doi.org/10.1111/jfb.12992

Hagihara, S., Yamashita, R., Yamamoto, S., Ishihara, M., Abe, T., Ijiri, S., \& Adachi, S. (2014). Identification of Genes Involved in Gonadal Sex Differentiation and the Dimorphic Expression Pattern in Undifferentiated Gonads of Russian Sturgeon Acipenser gueldenstaedtii Brandt \& Ratzeburg, 1833. Journal of Applied Ichthyology, 30, 1557-1564. https://doi.org/10.1111/jai.12588

Hurvitz, A., \& Markel, D. (2015). How to Run a Water Efficient Fish Farm? Israelagri. http://www.israelagri.com/?CategoryID=463\&ArticleID=1133

Hurvitz, A., Jackson, K., Degani, G., \& Levavi-Sivan, B. (2007). Use of Endoscopy for Gender and Ovarian Stage Determinations in Russian Sturgeon (Acipenser gueldenstaedtii) Grown in Aquaculture. Aquaculture, 270, 158-166.

https://doi.org/10.1016/j.aquaculture.2007.05.020

Jin, S. B., Zhang, Y., Dong, X. L., Xi, Q. K., Song, D., Fu, H. T., \& Sun, D. J. (2015). Comparative Transcriptome Analysis of Testes and Ovaries for the Discovery of Novel Genes from Amur Sturgeon (Acipenser schrenckii). Genetics and Molecular Research, 14, 18913-18927. https://doi.org/10.4238/2015.December.28.40

Sicuro, B. (2019). The Future of Caviar Production on the Light of Social Changes: A New Dawn for Caviar? Reviews in Aquaculture, 11, 204-219.

https://doi.org/10.1111/raq.12235

Wang, W., Zhu, H., Dong, Y., Tian, Z., Dong, T., Hu, H., \& Niu, C. (2017). Dimorphic Expression of Sex-Related Genes in Different Gonadal Development Stages of Sterlet, 
Acipenser ruthenus, a Primitive Fish Species. Fish Physiology and Biochemistry, 43, 1557-1569. https://doi.org/10.1007/s10695-017-0392-x

Озиранский, Ю., Колесник, Н. Л., Щербак, С. Д., Кононенко, Р. В., Федоренко, М. О., Мосницкий, В. А., \& Некрасов, С. А. (2017). Current State of Israel's Fisheries (Overview). Fisheries Research in Ukraine, 1, 6-28. 